\title{
KOMPETENCIÁK, SZTENDERDEK, INDIKÁTOROK, PORTFÓLIÓ
}

\author{
RiCZU JULIANNA* - TóTH LAJOS ÁRPÁD ** \\ * tankerületi igazgató, Hajdúböszörmény \\ julianna.riczu@klik.gov.hu \\ ** tankerületi igazgató, Nyíradony \\ arpad.lajos.toth@klik.gov.hu
}

\begin{abstract}
A tanulmány az életpályamodellhez és a minösitéshez kapcsolva feltárja azokat a szemléleti és gyakorlati korlátokat, azokat a félelmeket és bizonytalanságokat, amelyek természetes módon gátolják a pedagógusokat az új értékelési rendszer elfogadásában. Támaszt ad az új paradigma értelmezéséhez, kiemeli azokat a tényezöket, amelyek már ma is a pedagógusok mindennapi gyakorlatának sajátjai, s azokat, ahol a változtatásra valóban szükség van.
\end{abstract}

Azon a bizonyos forró augusztusi délelőttön még 2013-ban, egy nevelötestületi értekezleten keringtek ezek a szavak a tanteremben és a pedagógusok fejében, amikor a (még elfogadás alatt álló) nevezetes kormányrendelet alapján tartott tájékoztató alkalmával először hallottak az életpályamodellről, a pedagógus-értékelésröl. Tudták a szavak jelentését, de valahogy mégsem értették abban a kontextusban, amiben elhangzottak. Ma már mindenki érti, egy részük a gyakorlatban is tapasztalja az értékelés folyamatát, elkészítette, vagy éppen most készíti a portfólióját. Új idők új folyamatainak vagyunk tanúi. A magyar pedagógusok zöme ilyen típusú értékelési formával még nem találkozott, soha nem írt a saját munkájáról ilyen szisztematikusan, összefüggően megadott szempontok, elvárások alapján. Nem kényszerült arra, hogy elemezze saját magát, észrevegye hibáit, erényeit, és reflektáljon azokra. Sokan megértették az életpályamodell lényegét. Nemcsak anyagi előnyöket látnak benne, hanem a szakmai fejlődés egyik lehetőségét, a pedagóguspálya presztízsének emelkedését. Ahhoz, hogy helyén tudjuk kezelni ezeket az új jelenségeket, jót tesz egy kis elméleti és gyakorlati háttérismeret. Miért van szükség új pedagógiai szemléletre? Miért fontos az önreflexió? Mi a célja a portfóliónak? A kompetenciákat illetően mi az elvárás és mi a valóság? Tanulhatóak-e az indikátorok szerint vizsgált kompetenciák? Ezekre a kérdésekre keresünk választ előbb elméleti, majd gyakorlati megközelítésben.

Azon a nyár végi délelőttön még nem sok ismeretünk volt ezekről a dolgokról. Sem az előadónak (nekem), sem a hallgatóságnak (tankerületünk egyik nevelötestületének). Ma már egyre több. Minél több oldalról közelítünk, minél nagyobb a tudásunk, a nyugtalanság, az újtól való félelem, a szorongás egyre csökken. Bátrabban állhatunk a változó idők sodrában. 


\section{Előmeneteli rendszer - életpályamodell}

Úgy gondolom, hogy az előmeneteli rendszer változásai a rendszerváltást követő változások sok problémája közül egy, de fontos, ezáltal nem elhanyagolható, hiszen 160 ezer embert érint és általuk másfél millió gyermeket. A tényleges társadalmi változások egy része még csak most kezdődik, és egymás mellett élnek a régi viselkedési minták, a piacgazdaság mintái és ezek különböző kombinációi. Ez az átmeneti állapot abban mutatkozik meg látványosan, hogy a felnövekvő nemzedékek egyre bizonytalanabb értékrendet és normarendszert örökölnek, nincsenek felkészítve arra, hogy önállóan is el tudjanak igazodni az egyre bonyolultabbá váló társadalmi viszonyok között. Ebben az ellentmondásos helyzetben mit tehet, mit tegyen az iskola, az oktatásirányítás, a pedagógusok, a szülők, mit tegyünk mi valamennyien? A valóságos - dezintegratív - társadalmi folyamatokkal szemben hogyan örizze meg az iskola a korábbi integratív szerepét: a közös nyelv és müveltség közvetítését, a társadalmi különbségek kiegyenlítését, a társadalmi összetartozás erősítését? Mennyiben szolgáltatható ki az iskolarendszer korábban viszonylag zárt értékvilága a piacgazdaság és a globalizáció kihívásainak? Mennyire szolgálja ki az oktatási rendszer a munkaerőpiac meglehetősen leegyszerüsített, brutális igényeit?

Nagy változásokat kellett/kell indukálni, hogy az oktatás középpontjába a gyerekek kerüljenek a tananyag helyett. A tanárok is inkább szakértők, mint előadók, partnerek, a tanulási folyamat segítői kell, hogy legyenek. A szerepek megváltozása jelentette/jelenti a legnagyobb reformot az elmúlt évtizedekben.

Tudomásul kell/kellett vennünk, hogy napjainkban, az oktatás világában nagymértékü szemléletváltás figyelhető meg. A 19. században kialakult tömegoktatási modell (pedagógiai kultúra) mellett és helyett egyre inkább helyet követel magának egy radikálisan új pedagógiai szemlélet (paradigma), amely első megközelítésben az oktatás minöségére igyekszik nagyobb hangsúlyt helyezni. Ennek a szemléletnek az egyik alapvető eleme az ún. perszonalizáltság (személyre szabottság), ami azt jelenti, hogy az oktatási rendszer minél rugalmasabban alkalmazkodik a tanulók sajátos egyéni (személyes) szükségleteihez. A szemléletváltás másik fontos pillére az, hogy az iskolarendszer a korábbiaknál közvetlenebb módon kapcsolódik valóságos társadalmi (pl. munkaerö-piaci, illetve kohéziós) folyamatokhoz. A kétféle pedagógiai kultúra sok területen gyökeresen különbözik egymástól, ezért egymás mellett élésük nagyon sok kérdést és konfliktus vet majd fel a közeljövöben.

Mi következik számunkra mindebből? Nyilvánvalóan az a legfontosabb, hogy meg kellene ismerkednünk a pedagógiai szemléletváltás, illetve az új pedagógiai kultúra minden elemével, hogy eldönthessük, mennyiben tudjuk, illetve akarjuk azt követni. Úgy tünik azonban, hogy már maga a megismerés is komoly akadályokba ütközik, mert alapvetően különbözik a 19. századi hagyományokra épülő mai magyar iskolai gyakorlattól. Más szóval a paradigmaváltás olyan gyökeres, hogy a hagyományos értelmezési keretben - a régi szemüveggel - nem is lehet igazán reáli- 
san értelmezni, megitélni. Ebben a helyzetben nagyon könnyen félreértjük - mintha értenénk, már majdnem értjük - az új pedagógiai törekvéseket. Az ilyen jellegü „fél-értések” vagy félreértések azért veszélyesek, mert nagyon könnyen „,irreális valóságértelmezések" és öncsalások alapjaivá válhatnak.

Az ilyen típusú öncsalás az, amikor kizárólag a saját pedagógiai kultúránkba ágyazva értelmezzük az új jelenségeket. Nyilvánvaló, hogy ebben az esetben nem mindig látjuk meg az eltérések valóságos dimenzióit. Úgy érzékeljük, hogy lényegében mi is hasonló dolgokat csinálunk, legfeljebb nem olyan hangsúlyosan vagy csak más elnevezéssel. Az eltérés meglátásához azonban egy kicsit el kell távolodnunk a megszokott értelmezési keretektől.

Az új pedagógiai szemlélet fontos eleme az iskolák, ezáltal a tanárok, illetve a diákok teljesitményének folyamatos mérése. A személyközpontú, illetve kompetencia alapú iskolarendszer esetében ugyanis különösen fontos a folyamatos monitorozás: minden egyes diákot személyes fejlesztési stratégia alapján kell elörejuttatni. Ha azonban az oktatási rendszer többi eleme lényegében változatlan marad, akkor a legérzékenyebb mérési rendszer is csak a diákok által elsajátított tananyagmennyiséget tudja majd mérni.

A szemléletváltás jellegét és intézményi formáit minden országnak magának kell megtalálnia és megvalósítania. E szemléletváltásban segít a pedagógus életpályamodell kialakítása, és a benne megjelenő portfólió is, amely alapján végigkísérhető a pedagógus szakmai útja, tevékenysége, fejlődése, nehézségei és sikerei, egyrészt a tények tükrében, másrészt magának a pedagógusnak a reflexiói, értelmezése alapján. Mi a cél a portfólióval? Egyrészt a szakmai fejlődés folyamatos segítése, másrészt az életpálya egyes szintjein a feljebb lépést lehetővé tevő minősítés megalapozása.

Tudomásul kell venni, hogy a pedagógiai végzettség megszerzése még nem jelenti a pedagógussá válást is, csak lehetőséget, hiszen vannak olyan képességek, amiket munkája során sajátít el. A pedagógusnak, bármennyire is nehéz, el kell számolnia azzal, hogy milyen eredményt ért el eddigi munkája során. Fontos annak a gondolkodásnak az elsajátítása is, hogy a tanár a saját munkáját értékelni tudja, és a felmerülő problémákat képes legyen megoldani. Ha sikerül a saját tevékenységét ilyen megítélés alá vetnie, sokat profitálhat, hisz önmagát tudja folyamatosan fejleszteni.

Összességében elmondható, hogy a pedagógus portfólió összeállításának célja, hogy útmutatóként szolgáljon egy olyan szakmában, ahol folyamatos a fejlődés, ahol számítanak az egyéni képességek, és ami a legjelentősebb, generációk sokaságát nevelik. Lényeges kiszürni a tanári pályára alkalmatlanokat, és ugyanakkor fontos elismerni az arra alkalmasak képességeit.

Mit jelent pedagógusnak lenni egy olyan világban, amely tele van ellentmondással, nehezen értelmezhető változásokkal, hatalmas feszültségekkel? Nem mondhatjuk, hogy ez a szakma olyan mindennapokat ad a pedagógusoknak, ahol könnyen 
eligazodnak, jól kiérlelt módszerekkel eredményesen dolgozhatnak, és az erkölcsi, anyagi megbecsülés mértékével elégedettek lehetnek.

Napjainkban a pedagógia nagyon összetett társadalmi gyakorlattá vált, ezért a változó világ rákényszeríti a gyors megújulást az iskolára/pedagógusra is. Nem vitatható, hogy napjainkban a teljesebb mesterségbeli tudás egyre értékesebbé válik. Az új tanítási módszerek, a kapcsolati és irányítási készségek, a konfliktusmegoldás feszültségeket csökkentő módjai elengedhetetlenül a sikeres szakmai munka feltételeivé váltak. Ezekhez a feltételekhez sorolhatjuk még a reflektivitás képességét, a szakmai önértékelés forrásainak átgondolását, a változni tudás képességét és a kreativitás szükségességét, a viselkedés-repertoár gazdagságát.

Mit vár el ma a környezet, az iskola, a diák, a szülő a tanártól?

A hetvenes években jelent meg Marx György könyve, A gyorsuló idö, amiben pontosan erről beszélt: a jövőben elsősorban nem ismeretekkel kell felvértezni a tanulókat, mert tizenöt év alatt megfeleződik a tárgyi tudás. Amit az iskolában megtanul, nagyon hamar elévül, használhatatlanná válik, és a 21. században ez még fokozottabban igaz. Sokkal inkább arra kell megtanítani a diákokat, hogyan tegyenek szert a tudásra, ismeretekre. Ez összecseng az egész életen át tartó tanulás európai felfogásával.

Nyilvánvaló, hogy a tanuló csak akkor lesz erre képes, ha a pedagógus is képes rá. Az elvárások tekintetében nem sok lényegi változás történt. A pedagógusszerep felfogásában bekövetkezett módosulás nem az utóbbi harminc évben zajlott le, hanem már jóval korábban megkezdődött. Az alapvető fordulatot az jelentette - és ez megint csak a hetvenes évek közepére tehető -, amikor a tanári szerepről való gondolkodás megváltozott: az ismeretforrás helyett a tanár az ismeretek szervezője, rendszerezője legyen. Más szavakkal: a pedagógusnak már nem szereplönek, nem szinésznek, hanem rendezönek kell lennie. Tudnia kell azt is, hogy a hétköznapi gyakorlatban mire lehet használni ezeket az ismereteket. Képesnek kell lennie önállóan és folyamatosan megújítani a tudását, és képessé kell tenni erre a rá bízott gyerekeket is.

Az iskolai gyakorlatban két kiemelten fontos funkciója van/lesz a portfóliónak. Egyrészt a szakmai fejlődés folyamatos segítése, másrészt az életpálya egyes szintjein a feljebb lépést lehetővé tevő minősítés megalapozása. A rendszeres szakmai ellenőrzés-értékelés során a szakértők és szaktanácsadók számára fontos információforrás a pedagógus portfóliója, amelyet a támogatás/segítés szándékával elemeznek, értékelnek.

\section{Pedagóguskép, ahogyan eddig láttuk}

A pedagógus társadalom méltánytalanul „,szenvedett” évtizedeken keresztül a megbecsülés hiányától. Erkölcsi és anyagi szinten egyaránt. Magukra hagyta őket a társadalom, pártpolitikai határozatok megvalósítójává váltak az oktatási intézmények. 
Választások után zömében változtak a politikai erők is, ennek megfelelően az oktatásban zajló folyamatok is ilyen periódusokra oszthatók.

Ha végigkövetjük a közoktatás szabályozásának változásait (törvények, miniszteri rendeletek, kormányhatározatok, és az ezekre épülő belső szabályzatok) azt láthatjuk, hogy a rendszerváltás óta a pedagógusoknak ki kellett lépniük az addig rögzült szerepükből. A stabil szerep megszünt, ami egyben komoly bizonytalanságot is okozott. Egyre árnyaltabb összeszedettebb feladatellátást igényelt a szakmától. Miközben a társadalmi elvárások jelentősen megnövekedtek, (ennek megfelelően halmozódtak a betöltött szerepek) a pedagógusok helyzete, megítélése és megbecsülése, nagyfokú romlása között komoly ellentét alakult ki.

Azoknak, akik eddig csak pontos utasítások mentén végezhették a munkájukat, „egyik napról a másikra” pl. a pedagógiai programok megalkotásával, helyi tantervek kialakításával, nagymértékben megnőtt az autonómiája. Szükségessé vált, hogy a szaktárgyi szempontokon túllépve, össziskolai nézőpontból közeledjen az iskola nevelési-oktatási rendszeréhez. A feladatok újszerüségével egyesek nem tudtak vagy nem is akartak megbarátkozni. Gyakran kevesek vállára hullott az összes feladat. A nyitásra kész, nagyobb alkalmazkodó képességgel bírókat a munka mennyiségének terhe nyomta. Ennek ellenére minden intézményben kialakult egy megújulásra kész, kreatív „csapat”, akik megtanultak bánni az új szereppel, igen komoly pedagógiai értéket teremtve. Az egyenletes terhelésről, munkamegosztásról nem nagyon beszélhettünk az elmúlt években.

A pedagógusok azonban nemcsak a feladatok elvégzése során maradtak magukra, hanem szakmai tekintetben is. Ez alatt az ellenőrzés teljes hiányát értem, kivételt képez az a néhány intézmény, ahol ezekben az években is igen komoly külső és belső ellenőrzés történt, meg persze a fenntartó által megrendelt szakértői „,segítséget”, akik „elöre gyártott” sablonok alkalmazásával ellenőrizték a dokumentumokat, ügyelve arra, hogy többletköltség ne jelentkezzen. De a pedagógusok zöme semmiféle visszajelzést nem kapott munkájának minőségéről, kivéve a belső intézményvezetői, munkaközösség-vezetői óralátogatásokat - már ott, ahol volt ilyen. A szakmai ellenőrzés hiánya bizonytalansághoz, vagy ennek éppen az ellenkezőjéhez, egy téves énkép kialakulásához vezetett.

\section{A változások szele}

Az elmúlt választások után gyökeres változások ingatták meg az egész oktatási rendszert, óvodától a felsőoktatási intézményekig. Az életpályamodell bevezetése, az amúgy karrierlétra nélküli pályát alapjaiban változtatta meg. Társult ehhez egy viszonylag jelentős béremelés is. A Pedagógus I. kategóriába történt csaknem egységes besorolás azonban sokkolta a pedagógustársadalmat (az okokat ismerjük).

Az állami fenntartásba vétel viharos gyorsasága, a 32 órás „benntartózkodás” kötelezettsége, a helyettesítésért és túlmunkáért járó bérezés elmaradása stb. sem 
aratott osztatlan sikereket. A portfólió elkészítésével kapcsolatban is vegyes volt a fogadtatás. A szakvizsgázott és előírt szolgálati idővel rendelkező tanárok egyszerüsített e-portfólió elkészítésére is nagyon gyorsan kellett reagálni az érintetteknek. Sok volt (van) közöttük az 50-es éveiben járó szakember, akiknek nem mindegyike rendelkezik kellő tudással az informatika terén. Többen elvből tiltakoztak, mások viszont lendületesen hozzáfogtak az elkészítéséhez. „Az Európai Unio legtöbb tagállamához hasonlóan Magyarországon is müködni kezd egy egységes, nyilvános szempontsor alapján kialakított, rendszeres külső szakmai ellenőrzés, értékelés." (Oktatási Hivatal, Országos tanfelügyelet.)

A pedagógusok munkájának ellenőrzése egy merőben új, országos szintü, egységes eljárás. Célja, a tanárok alkalmasságának, a szakmai munka hatékonyságának, a hozzáadott pedagógiai értékek feltárásának, az erősségeknek, a fejlesztendő területeknek a feltárása. Az előmeneteli rendszer egyik alappillére a kompetenciaterületeknek való megfelelés, vagyis hogyan valósulnak meg a gyakorlatban a kimeneti követelményként elöírt kompetenciák (A tanári felkészítés közös követelményeiről és az egyes tanárszakok képzési és kimeneti követelményeiről szóló 8/2013.(I.30.) EMMI rendelet alapján.).

\section{Kompetenciák, indikátorok, sztenderdek}

Nyolc kompetenciaterületet vizsgálunk.

1. Szakmai feladatok, szaktudományos, szaktárgyi, tantervi tudás.

2. Pedagógiai folyamatok, tevékenységek tervezése és a megvalósításukhoz kapcsolódó önreflexiók.

3. A tanulás támogatása.

4. A tanuló személyiségének fejlesztése, az egyéni bánásmód érvényesülése, a hátrányos helyzetü, sajátos nevelési igényủ vagy beilleszkedési, tanulási, magatartási nehézséggel küzdő gyermek, tanuló többi gyermekkel, tanulóval együtt történő sikeres neveléséhez, oktatásához szükséges megfelelő módszertani felkészültség.

5. A tanulói csoportok, közösségek alakulásának segítése, fejlesztése, esélyteremtés, nyitottság a különböző társadalmi-kulturális sokféleségre, integrációs tevékenység, osztályfönöki tevékenység.

6. Folyamatok és a tanulók személyiségfejlődésének folyamatos értékelése, elemzése.

7. Kommunikáció és szakmai együttmüködés, problémamegoldás.

8. Elkötelezettség és szakmai felelősségvállalás a szakmai fejlődésért.

Mindegyik területhez indikátorok kapcsolódnak, melyek lehetővé teszik az egységes szempontok szerinti értékelést, nyilvánosságuk mindenki számára lehetővé teszi az egységes szempontok szerinti tervezést, végső soron a szakmai autonómia megtartá- 
sa mellett a nevelö-oktató munka egységesítéséhez vezet el. Ez alkalommal egy kompetenciaterületet elemzünk, mert mind a nyolc terület elemzése, összevetése a valós és az elvárt pedagóguskép között, sokkal nagyobb terjedelmet igényelne.

\section{A „Kommunikáció és szakmai együttmüködés, problémamegoldás” kompetencia részletes elemzése a megújítás nézőpontjából}

A hetedik kompetencia a pedagógus egész személyiségére kiterjed, képet ad a tanár jelleméről, attitűdjeiről, személyiségjegyeiröl.

Indikátorok:

1. A kommunikáció a partnerekkel. A pedagógusok munkája interperszonális közegben történik (tanár - diák, tanár - tanár, tanár - szülő, tanár - külső kapcsolatokban megjelenő személyek stb.). A kommunikációs képességek magas szintje elengedhetetlen, ám a gyakorlat nem minden esetben mutatja ezt. Sokszor finomítani lehetne a tanulókkal való kommunikáción, a kollégákkal, szülőkkel való párbeszéden. Ez az elvárás fokozottan érvényes, hiszen a gyerekekről szól, éppen ezért nagyon érzékeny terület. Sok függ a pedagógus stílusától, habitusától, de megtanulható kompetenciának tartjuk.

2. A kapcsolattartás formái, az együttmüködés során az infokommunikációs eszközök használata még ,gyerekcipőben” jár, fokozottan igaz ez az idősebb kollégákat illetően. Pedig nagyon fontos terület, mert pontosan ez az a csatorna, amit a diákok a legtöbbet használnak. E csatornán gyakorlatilag minden tanítvány elérhető, mindegyikük megközelíthető. Tapasztalataink szerint az elvárt szinttől a pedagógusok jelentős hányada még nagyon távol jár, inkább a fiatalokra jellemző, s még a tantestületen belül is generációs problémát jelez.

3. A nyitott szemléletű pedagógus nem ritka, jelen vannak minden nevelőtestületben, és többféle módon fellelhető. Szabadidő szervezésénél, kirándulások lebonyolításánál, DÖK programok összeállításánál, szülőkkel való közös rendezvények megvalósításánál a pedagógusok zöme nyitott, demokratikus. A szakmai munkáról szóló visszajelzések azonban érzékenyen érintik, fóként, ha negatív felhangot is tartalmaznak, és a tanulók vagy a kollégák részéről érkezik a kritika. Úgy gondoljuk, ennek az az oka, hogy még nem alakult ki az önreflexió gyakorlata. Ha ez gyakoribb lenne, a negatív visszajelzéseket a fejlesztendő területek kijelölésére használhatnák.

4. A diákok érdekében önálló, tudatos és kezdeményező együttműködés a partnerekkel a leginkább megvalósuló terület. A pedagógusok jelentős része a tanítványok érdekeit helyezi előtérbe munkája során, leginkább itt jelenik meg a pálya hívatás jellege. 
5. Szakmai álláspont kifejtése, viták minősége. Ez az az indikátor, amely leginkább függ a pedagógus személyiségjegyeitől. Azt gondoljuk, egy nevelötestületi értekezleten mindenkinek van véleménye, de annak kommunikálását többnyire az ,ügyeletes hozzászólók” vállalják. A konfliktuskerülő, visszahúzódó emberek nemigen nyilvánulnak meg, ennek okai a legkülönfélébbek lehetnek. Van, aki lámpalázas, van, aki fél az esetleges következményektől, de természetesen sokan vannak azok is, akik vállalják a konfrontálódást, okosan érvelnek valami mellett vagy éppen ellen. A szakma társadalmi presztízsének növekedésével nő a tanárok önbizalma is. A rendszeres minősítés elvezethet az érvelési technikák fejlődéséhez, a vitakultúra csiszolódásához.

6. Tevékenység során felmerülő feladatok/problémák önálló intézése. Az intézményekben folyó tevékenységek igen széles skálán mozognak. Ismereteim szerint a tanárok feladattudata a helyén van, ismertek a szervezet müködési mechanizmusai, dokumentumai, eljárásrendjei melyek mentén az egyedi problémák megoldása is a szervezeti egység jegyében történik. Az utóbbi egy esztendő során az együttmüködést segítő tényezővé vált a 32 órás intézményben tartózkodásra vonatkozó rendelkezés, mely az egyenlő leterheltséget is eredményezi, de legalábbis közelíti.

7. Szakmai munkaközösségben való együttmüködés. A szakmai munkaközösségek szerepe a módszertani kultúra, a különböző munkaformák gazdagodásával felerősödött, egyre inkább kilép a formalitás szürkeségéböl. E kisebb közösségben az ötödik indikátornál nevesített „csendesebb” pedagógusok is kiteljesedhetnek, föként akkor, ha a vezetö ismeri a tagok erősségeit. Úgy tapasztaljuk, hogy szakmai munkaközösségek ébredezni kezdenek, az együttmüködési kompetencia sokkal inkább tetten érhetö, mint korábban. Eltünőben van a „szakmai féltékenység” jelensége.

8. Hatékony, nyugodt kommunikációs tér kialakítása a tanuláshoz. Ez egy nagyon fontos eleme a színvonalas pedagógiai munkának. Az állandóan „ordibáló" diákok, az azokra ordibáló tanárok riasztó képe sokunk által ismert. A nyugodt légkör kialakításához nyugodt nevelö kell. A feltételeket mindenki maga tudja alakítani a saját egyéniségével, igényességével. Ez a múltban is, most is müködhet jól és rosszul. A nevelötestület tagjai e kompetencia és az indikátor fejlesztésében.

9. Érthető, pedagógia céljainak megfelelő kommunikáció. A pálya iránt elkötelezett pedagógus nem is tehet másként. A gyakorlatban azonban sokszor találkozunk olyan képpel, ahol a tanár „kioktat”, mind a tanítványok, mind a szülők részéről érkezik ilyen jelzés. Ha megfelelő stílusban, higgadtan, okosan történik a kommunikáció, a tanár érvényesítheti az értékeit. Tapasztalatok útján tudatosan fejleszthető területnek tartom. 
Új indikátor; Nem vét a pedagóguspálya jogi és etikai szabályai ellen. A pedagógusok jogállása tisztázott, ismert. Kevés olyan esetről hallunk, ahol jogsértéseket követnek el az iskola falain belül. Az etikai szabályok betartása kényesebb terület. Természetesen minden pedagógus ismeri ezeket a ma még íratlan szabályokat (viták kereszttüzében „készülődik” az etikai kódex). Viszont a pálya sajátosságaiból nagyon nyitott az életük, föként a kisebb településeken, ahol gyakorlatilag a nap minden percében szem elött van, magánéletének mozzanatai láthatóak. A tanár kényes határmezsgyén mozog a tanítási idő, az intézményben eltöltött idő és a magánélet között. Az etikus magatartás azonban mindenképpen követelmény, hiszen példa az egész személyiség!

Összegzésként elmondható, hogy a vizsgált kompetencia elvárt és valós képe között nincs feloldhatatlan ellentét. Az elvárások reálisak, segítik a szakmai munka színvonalának emelését, jól illeszthetők a személyiség egységébe. Ahol hiányosságok jelentkeznek tudatos, tervezett tanulással, megfelelő visszacsatolással jól fejleszthető kompetenciaterület.

\section{Irodalom}

A nemzeti köznevelésről szóló 2011. évi CXC. Törvény.

A pedagógusok előmeneteli rendszeréről és a közalkalmazottak jogállásáról szóló 1992. évi XXXIII. törvény köznevelési intézményekben történő végrehajtásáról szóló 326/2013. (VIII.30.) Korm. Rendelet.

A tanári felkészítés közös követelményeiröl és az egyes tanárszakok képzési és kimeneti követelményeiröl szóló 8/2013.(I.30.) EMMI rendelet.

Kotschy Beáta (szerk., 2011): A pedagógussá válás és a szakmai fejlődés sztenderdjei. Módszertani kiadványok. Eszterházy Károly Főiskola, Eger. URL: www.epedner.ektf.hu/ eredmenyek/a_pedagogussa_valas_es_a_szakmai_fejlodes_sztendnderdjei.pdf Utolsó letöltés: 2015. 12. 31.

Marx György (1972): A gyorsuló idő. Kriterion, Bukarest. 